\title{
Copper Bromide as an Efficient Solution-Processable Hole Transport Layer for Organic Solar Cells: Effect of Solvents
}

\author{
Ranoo Bhargav, ${ }^{\dagger \neq}$ Neeraj Chaudhary, ${ }^{\dagger}$ Sweety Rathi, ${ }^{\dagger}$ Shahjad, ${ }^{\dagger, \ddagger}$ Dinesh Bhardwaj, ${ }^{\dagger, \ddagger}$ Sonal Gupta, ${ }^{\dagger \neq}$ \\ and Asit Patra $*, \dagger, \ddagger$
}

${ }^{\dagger}$ Photovoltaic Metrology Section, Advanced Materials \& Device Metrology Division, CSIR-National Physical Laboratory, Dr. K. S.
Krishnan Marg, New Delhi 110012, India
${ }^{\ddagger}$ Academy of Scientific and Innovative Research (AcSIR), Ghaziabad 201002, India

Supporting Information

ABSTRACT: In this work, we report copper bromide $(\mathrm{CuBr})$ as an efficient, inexpensive, and solutionprocessable hole transport layer (HTL) for organic solar cells (OSCs) for the first time. To examine the effectiveness of the material in general, three different solvents such as acetonitrile (MeCN), dimethyl sulfoxide (DMSO), and dimethylformamide (DMF) are used for solution-processing thin-film deposition of $\mathrm{CuBr}$. $\mathrm{CuBr}$ thin films deposited from different solvents show high transparency and no significant difference has been observed in absorption in the visible and near-IR range, whereas a slight difference has been found in the near-UV range by changing the solvents. Furthermore, two most studied combinations of the active layer such as PTB7/PC 71 BM and PCDTBT:/ $\mathrm{PC}_{71} \mathrm{BM}$ are used for device fabrication with geometry of $\mathrm{ITO} / \mathrm{CuBr}(\mathrm{HTL})$ active layer/Al. By using $\mathrm{CuBr}$ as a $\mathrm{HTL}$ in OSCs, the power conversion efficiencies (PCEs) have been achieved to up to 5.16 and $4.72 \%$ with $\mathrm{PTB} 7 / \mathrm{PC}_{71} \mathrm{BM}$ and $\mathrm{PCDTBT} / \mathrm{PC}_{71} \mathrm{BM}$ active layers, respectively. The $\mathrm{CuBr}$ film from DMF solvent shows highest PCE as compared to films deposited from DMSO and MeCN solvents. Different solvents used for HTL deposition have a major effect on the fill factor (FF), while very little difference on open

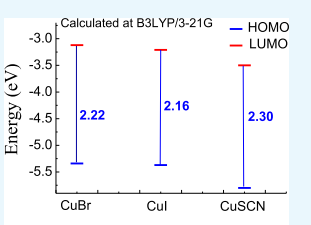
circuit voltage $\left(V_{\text {oc }}\right)$ and short circuit current $\left(J_{\mathrm{sc}}\right)$ has been observed. It may be mentioned here that a small difference of device parameters (PCE, FF, $J_{\text {sc }}$ and $V_{\text {oc }}$ ) has been observed in the devices using the HTL deposited from DMF and DMSO solvents, whereas a significant difference of the device parameters has been found in devices using the HTL from $\mathrm{MeCN}$ solvent.

\section{INTRODUCTION}

Solution-processable organic solar cells (OSCs) have been widely studied because of their easy fabrication process, costeffectiveness, light weight, flexibility, and large area as well as continuous improvement in their performance by the use of new materials and device architectures. ${ }^{1,2}$ These cells based on a bulk heterojunction concept have been fabricated with five different components such as indium tin oxide as an anode electrode, hole transport layer (HTL), active layer (donor/ acceptor), electron transport layer, and low work function (WF) metals used as a cathode electrode. It is a well-known fact that the performance of OSCs is highly dependent on the interface between the conductive electrode (anode or cathode) and active layer. ${ }^{3,4}$ An interface layer, namely, HTL is inserted between the anode electrode and active layer to improve the extraction and collection of charge carriers as well as stability and performance of the devices. A wide range of materials were used as HTLs in OSCs, out of which solution-processable materials are the most attractive choice because of costeffectiveness and easy fabrication process. Poly(3,4-ethylenedioxythiophene)/poly(styrenesulfonate) (PEDOT/PSS) is a well-known and most widely used solution-processable HTL material in the field of OSCs because of its high conductivity, transparency, and suitable WF. ${ }^{5,6}$ While because of the acidic and hygroscopic nature of PSS, it is a major cause of device degradation and stability. ${ }^{7,8}$ To overcome this problem, a series of new organic and inorganic alternative HTL materials have been developed and investigated as a replacement of PEDOT/ PSS such as PSS-free PEDOT, ${ }^{9-12}$ small molecules, graphene oxide, ${ }^{13}$ carbon nanotubes, ${ }^{14}$ polyaniline, ${ }^{15}$ and transitionmetal oxides ${ }^{16,17}\left(\mathrm{~V}_{2} \mathrm{O}_{5}, \mathrm{MoO}_{3}, \mathrm{NiO}\right.$, etc. $)$. The transitionmetal oxides have high air stability and optical transparency but insoluble in most of the common organic solvents. Because of solubility issue, these inorganic materials are usually deposited by vacuum deposition techniques, ${ }^{18}$ which is an incompatible, expensive, and more complicated procedure with the concept of cost-effective large-area OSC fabrication. To overcome the issue of vacuum deposition of inorganic HTLs, significant efforts have been studied for the development of solution-processable materials. Consequently, solution-processing methods have been reported by using different materials such as inorganic precursors, ${ }^{19}$ nanoparticles, ${ }^{20}$ colloidal particles, ${ }^{21}$ and so forth. Indeed, several solutionprocessable metal oxides, such as $\mathrm{CuO}_{x}{ }^{22} \mathrm{MoO}_{x}{ }^{23-25} \mathrm{ReO}_{x}{ }^{26}$ $\mathrm{VO}_{x}{ }^{27,28} \mathrm{NiO}_{x}{ }^{29,30} \mathrm{SnO}_{x},{ }^{31} \mathrm{WO}_{3}{ }^{32}$ and $\mathrm{RuO}_{x}{ }^{33}$ have been reported for relatively stable OSCs. Likely, these materials have

Received: October 31, 2018

Accepted: March 11, 2019

Published: March 29, 2019 
issue on relatively poor solubility, required specific solvents, toxicity, and shortage, which limits their possible commercial applications. Therefore, an alternative is required to develop a new cost-effective and efficient solution-processable HTL for OSCs. In particular, high solubility and earth-abundant HTL materials may be promising candidates for cost-effective photovoltaic applications.

Recently, a new series of copper-based materials such as copper iodide $(\mathrm{CuI})$ and copper thiocyanate $(\mathrm{CuSCN})$ have been introduced as solution-processable, robust, and highly transparent HTL materials for efficient OSCs. ${ }^{34}$ Indeed, $\mathrm{CuSCN}$ is an excellent solution-processable HTL for OSCs reported in many studies, ${ }^{35-37}$ but solubility of $\mathrm{CuSCN}$ in nasty solvents (diisopropyl sulfide) has limited its general applications. Solution-processable $\mathrm{CuI}$ has also been reported in the literature ${ }^{38-42}$ as a HTL in OSCs, while most of the studies have reported on poly(3-hexylthiophene)/[6,6]phenylC ${ }_{61}$-butric acid methyl ester $\left(\mathrm{P} 3 \mathrm{HT} / \mathrm{PC}_{61} \mathrm{BM}\right)^{43}$-based OSCs as a replacement of PEDOT/PSS. ${ }^{38,39}$ Very recently, Zhang et al. reported a thermal deposition of combination of $\mathrm{CuBr}_{2}$ and $\mathrm{MoO}_{3}$ as a HTL of inverted-type polymeric solar cells. ${ }^{44} \mathrm{Kim}$ et al. reported the templating effects on the growth of the organic molecules by using the thermal deposition $\mathrm{CuCl}$, $\mathrm{CuBr}$, and $\mathrm{CuI}$, possessing different lattice spacing by thermal deposition. $^{45}$ Zhao et al. used $\mathrm{CuBr}$ salt to enhance the conductivity of PEDOT/PSS and used for OSCs based on PCDTBT $/ \mathrm{PC}_{71} \mathrm{BM}^{46}$ With respect to the transition metalbased HTL on OSCs, practically nothing is known about solution-processable $\mathrm{CuBr}$ as a HTL in OSCs. It is noteworthy to mention that Müllen-Buschbaum and co-workers reported that the influence of the solvents on the thin-film morphology and structure should be resolvable by volume-sensitive methods. ${ }^{47}$ They were extensively investigated by the effect of solvent on the morphology and volume of the thin film for OSCs and vertical and lateral phase separation have been found during spin-coating and annealing temperature depending on the solvent. ${ }^{47}$ Furthermore, the effects of solvent on the interface and active layer in OSCs have also been reported in several publications. ${ }^{48}$

Here, for the first time, we have reported a solutionprocessable $\mathrm{CuBr}$ as an efficient, inexpensive, and solutionprocessable HTL for OSCs. The effectiveness of the material was examined by using three different solvents [acetonitrile $(\mathrm{MeCN})$, dimethyl sulfoxide (DMSO), and dimethylformamide (DMF)] for solution-processing thin-film deposition. The $\mathrm{CuBr}$ thin films deposited from different solvents were characterized by UV-vis spectroscopy and atomic force microscopy (AFM). For better understanding, two most studied combinations of active layers such as $\mathrm{PTB} 7 / \mathrm{PC}_{71} \mathrm{BM}$ and $\mathrm{PCDTBT} / \mathrm{PC}_{71} \mathrm{BM}$ were used for device fabrication with the device geometry of ITO/CuBr (HTL)/active layer/Al.

\section{RESULTS AND DISCUSSION}

2.1. Optical Measurement. Absorption spectra of solution-processed $\mathrm{CuBr}$ films in different solvents were performed on quartz substrates to understand the absorption in the range of the solar spectrum. $\mathrm{CuBr}$ films exhibit the absorption in the UV region (around $<500 \mathrm{~nm}$ ) as shown in Figure 1a. There is no significant difference observed in absorption spectra in the visible and near-IR range, whereas a slight difference has been found in the near-UV range by changing the solvents because solvents do not change the optical properties but change the morphology of the films.
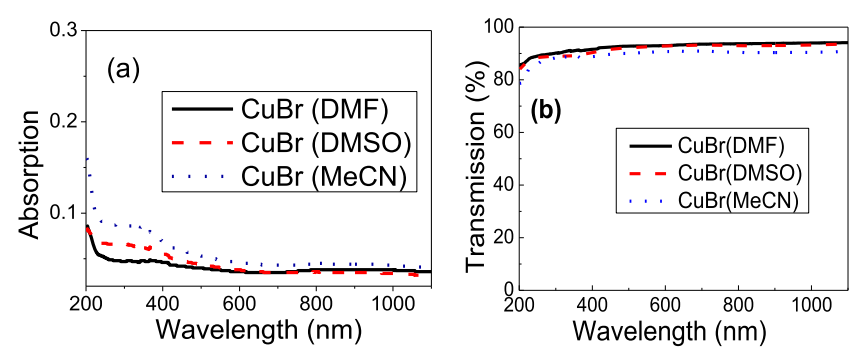

Figure 1. (a) Absorption and (b) transmission spectra of $\mathrm{CuBr}$ thin film from different solvents.

Therefore, it is clear that the $\mathrm{CuBr}$ films show lower parasitic absorption which makes them efficient HTLs for OSCs to further improve the power conversion efficiency (PCE).

Similarly, transmission spectra of $\mathrm{CuBr}$ films deposited with different solvents on quartz substrates are shown in Figure $1 \mathrm{~b}$. All these films deposited in different solvents are quite similar and show high transparency in the range of 300-1100 nm. $\mathrm{CuBr}$ films show high transparency around $\sim 87 \%$, which was comparable or even better compared to PEDOT/PSS, CuI, $\mathrm{CuSCN}$, and other transition-metal oxides. The transmittance of the $\mathrm{CuBr}$ films reduces slightly in the $\mathrm{UV}$ region $(>300 \mathrm{~nm})$. High transmittance of $\mathrm{CuBr}$ (HTL) films makes it a potential candidate for OSCs.

2.2. Computational Results. Energy-level alignments of the materials used for photovoltaic application play a very crucial role in $V_{\text {oc }} J_{\text {sc }}$ excitons dissociation, charge transport, and collection as well as on the device performance. Especially, the work function of the HTL has a potential role on charge transport and collection. The energy levels of optimized materials (see Supporting Information) such as $\mathrm{CuBr}$ along with $\mathrm{CuI}$ and $\mathrm{CuSCN}$ were calculated at the B3LYP/3-21G level of theory. It is notable that, in contrast to many ab initio methods (such as MP2, CISD, CCSD, etc.), the B3LYP level is always well acceptable for the predication of energy levels. The calculated highest occupied molecular orbital (HOMO), lowest unoccupied molecular orbital (LUMO), HOMOLUMO gap, and bond distance of these molecules are presented in Table 1 and Figure 2.

Table 1. Calculated Energies of HOMO, LUMO, HOMOLUMO Gaps, and Bond Distance at the B3LYP/3-21G Level of Theory

$\begin{array}{lccccc}\text { material } & \begin{array}{c}\text { HOMO } \\ (\mathrm{eV})\end{array} & \begin{array}{c}\text { LUMO } \\ (\mathrm{eV})\end{array} & \begin{array}{c}\text { HOMO-LUMO } \\ \text { gap }(\mathrm{eV})\end{array} & \begin{array}{c}\text { bond } \\ \text { distance } \\ \mathrm{Cu}-\mathrm{X}\end{array} \\ \mathrm{CuBr} & -5.34 & -3.12 & 2.22 & 2.175 & \text { WF }(\mathrm{eV}) \\ \mathrm{CuI} & -5.37 & -3.21 & 2.16 & 2.421 & 5.17^{b 49} \\ \mathrm{CuSCN} & -5.80 & -3.50 & 2.30 & 2.076 & 5.35^{b 36}\end{array}$

${ }^{a}$ Estimated work function from calculation. ${ }^{b}$ Experimental work function.

The calculated band gaps (at B3LYP/3-21G) of CuBr, CuI, and $\mathrm{CuSCN}$ are $2.22,2.16$, and $2.30 \mathrm{eV}$, respectively, with HOMO levels $-5.34,-5.37$, and $-5.80 \mathrm{eV}$, respectively (Table 1). It was observed that the HOMO level of $\mathrm{CuBr}$ is slightly lower $(0.03 \mathrm{eV})$ than that of $\mathrm{CuI}$, whereas it is about $0.46 \mathrm{eV}$ lower compared to $\mathrm{CuSCN}$ (Figure 3). The experimental work functions of $\mathrm{CuI}$ and $\mathrm{CuSCN}$ are 5.10 and $5.35 \mathrm{eV}$, respectively, ${ }^{36,49}$ while calculated HOMO levels 


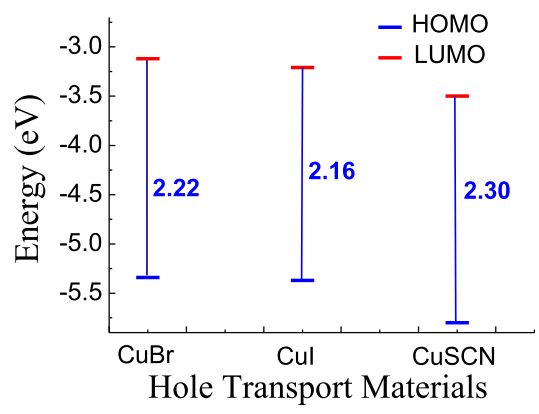

Figure 2. HOMO and LUMO energies of HTL materials calculated at the B3LYP/3-21G level of theory.

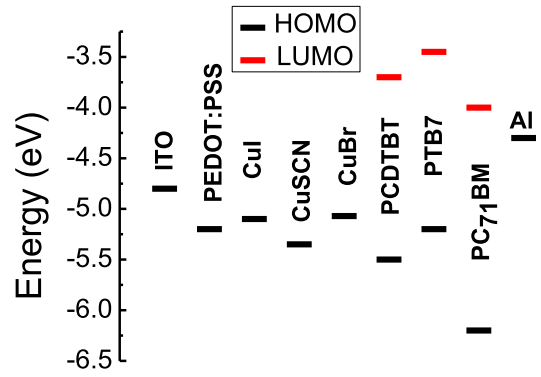

Figure 3. Energy band diagram of the photovoltaic materials.

are -5.37 and $-5.80 \mathrm{eV}$, respectively, shown in Table 1 . Therefore, such calculation systematically overestimates the HOMO level of $\mathrm{CuI}$ and $\mathrm{CuSCN}$ by $\sim 0.3-0.4 \mathrm{eV}$ because the B3LYP method apparently does not consider the sufficient electron correlation to correctly predict the energy levels.

If a correction of only $0.27 \mathrm{eV}$ (like $\mathrm{CuI}$ ) is applied between experimental and calculated values, then the estimated work function of $\mathrm{CuBr}$ is $5.07 \mathrm{eV}$ as shown in Table 1. The energy band diagrams of the materials used in study along with $\mathrm{CuBr}$, $\mathrm{CuI}$, and $\mathrm{CuSCN}$ are presented in the Figure 2. Therefore, $\mathrm{CuBr}$ may be a better hole extraction layer because of its slightly higher lying work function $(5.07 \mathrm{eV})$ compared to other most studied HTL materials like PEDOT/PSS (5.20 $\mathrm{eV}), \mathrm{CuI}(5.10 \mathrm{eV})$, and $\mathrm{CuSCN}(5.35 \mathrm{eV})$.

Moreover, $\mathrm{CuBr}$ can easily restrict the transport of electron to the anode electrode because of its higher lying LUMO level than the LUMO levels of active materials PCDTBT, PTB7, and $\mathrm{PC}_{71} \mathrm{BM}$. It is noted that both $\mathrm{CuBr}$ and active-layer materials like PCDTBT and PTB7 are hydrophobic in nature, which may offer good compatibility and ordering to decrease the contact resistance between the active layer and HTL.

To examine the effectiveness of $\mathrm{CuBr}$ as an important solution-processable HTL material for OSCs, we consider conventional device geometry ITO/HTL/active layer/Al as presented in Figure 4. Two most important donor polymers PTB7 and PCDTBT blended with $\mathrm{PC}_{71} \mathrm{BM}$ were used as the active layer for device fabrication. The chemical structures of these materials are also presented in Figure 4.

2.3. Photovoltaic Device Characteristics Result. To study the performance of $\mathrm{CuBr}$ as an $\mathrm{HTL}$, we have fabricated conventional device structure ITO/CuBr/active layer/Al. The concentration of the $\mathrm{CuBr}$ solution and thickness of the HTL were optimized (conditions are mentioned in Experimental Section) to reach the maximum possible efficiency of the device. The optimization process is used throughout the further study. Figure 5 displays the current density voltage $(J-$

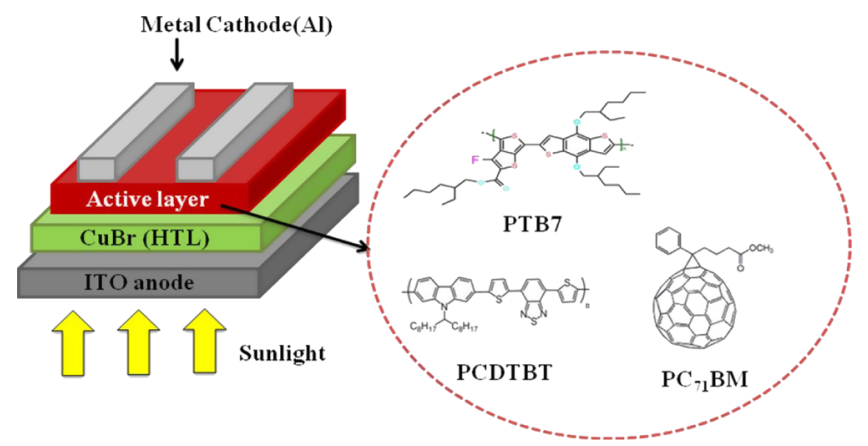

Figure 4. Device geometry of OSCs with $\mathrm{CuBr}$ as HTL and the chemical structures of organic materials used in the active layer.

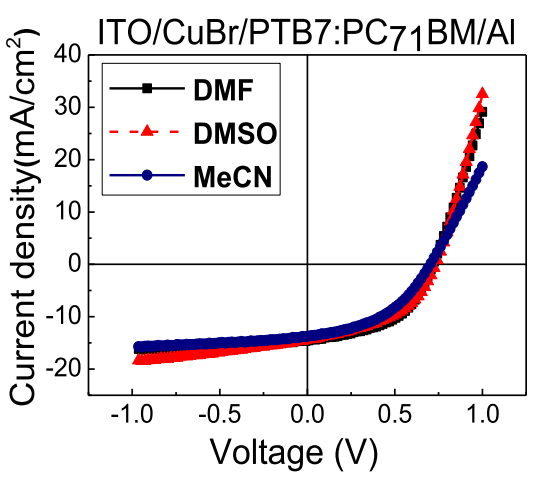

Figure 5. $J-V$ characteristics of $\mathrm{PTB} 7 / \mathrm{PC}_{71} \mathrm{BM}$ devices under illumination conditions.

$V)$ characteristics of the CuBr-based device using PTB7/ $\mathrm{PC}_{71} \mathrm{BM}$ as an active layer under illuminations (Figure S5 for $J-V$ curve under dark). The OSC results of these devices extracted from the $J-V$ measurements are presented in Table 2. To investigate the effect of solvents on the device performance, three different solvents (DMF, DMSO, and $\mathrm{MeCN}$ ) were used. We found that the $\mathrm{CuBr}$ thin film that was deposited from DMF solvent as a HTL in the device shows the highest PCE of $5.16 \%$ with short-circuit current $\left(J_{\mathrm{sc}}\right)$, open circuit voltage $\left(V_{\mathrm{oc}}\right)$, and fill factor $(\mathrm{FF})$ are $14.62 \mathrm{~mA} / \mathrm{cm}^{2}$, $0.72 \mathrm{~V}$, and $50 \%$, respectively, as presented in Table 2 . While $\mathrm{CuBr}$ thin films were deposited from DMSO and $\mathrm{MeCN}$ solvents show slightly lower PCE of 4.81 and 4.25\%, respectively.

In order to further examine the effectiveness of $\mathrm{CuBr}$ as a solution-processable HTL on device performance, another well-studied donor polymer PCDTBT was selected for our further study. In this study, the optimized concentration of $\mathrm{CuBr}$ was used for the device fabrication with the same device geometry and the three solvents. Figure 6 shows the $J-V$ characteristics under illumination conditions, respectively, and the dark curve (Figure S6) shows diode characteristics. Similar to a previous study, the DMF solvent device exhibits the highest PCE of $4.72 \%$ with $J_{\mathrm{sO}} V_{\mathrm{oC}}$ and FF being $10.04 \mathrm{~mA} /$ $\mathrm{cm}^{2}, 0.87 \mathrm{~V}$, and $53.9 \%$, respectively, as presented in Table 2 . However, the $\mathrm{CuBr}$ thin films that were deposited with DMSO and $\mathrm{MeCN}$ show lower PCE of around 4.51 and 3.30\%, respectively. It may be mentioned here that for comparison purpose, devices were fabricated without using the HTL under identical conditions as described above, and very poor PCE $\sim 0.37$ and $\sim 0.26 \%$ have been achieved in device configuration 
Table 2. Device Results of OSCs Based on the CuBr as a HTL with Different Solvents (Average of 4 Devices)

\begin{tabular}{cccccc}
\hline active layer & $\mathrm{CuBr}$ in different solvents & $J_{\mathrm{sc}}\left(\mathrm{mA} / \mathrm{cm}^{2}\right)$ & $V_{\mathrm{oc}}(\mathrm{V})$ & $\mathrm{FF}(\%)$ & $\mathrm{PCE}(\%)$ \\
$\mathrm{PTB7} / \mathrm{PC}_{71} \mathrm{BM}$ & $\mathrm{DMF}$ & 14.62 & 0.72 & 50.0 & $5.16( \pm 0.16)$ \\
& DMSO & 14.41 & 0.72 & 46.1 & $4.81( \pm 0.19)$ \\
& $\mathrm{MeCN}$ & 13.81 & 0.68 & 44.7 & $4.25( \pm 0.24)$ \\
$\mathrm{PCDTBT} / \mathrm{PC}_{71} \mathrm{BM}$ & $\mathrm{DMF}$ & 10.04 & 0.87 & 53.9 & $4.72( \pm 0.23)$ \\
& DMSO & 10.45 & 0.85 & 50.6 & $4.51( \pm 0.14)$ \\
& MeCN & 9.50 & 0.80 & 43.5 & $3.30( \pm 0.19)$ \\
\hline
\end{tabular}

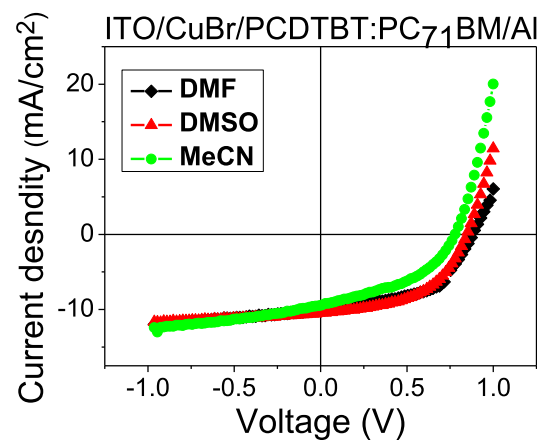

Figure 6. $J-V$ characteristics of $\mathrm{PCDTBT} / \mathrm{PC}_{71} \mathrm{BM}$ devices under illumination conditions.

of ITO/PTB7/PC ${ }_{71} \mathrm{BM} / \mathrm{Al}$ and ITO/PCDTBT/PC ${ }_{71} \mathrm{BM} / \mathrm{Al}$, respectively, as presented in Figure $\mathrm{S} 7$.

It was observed that under identical conditions, all the devices show very good performance, while the $\mathrm{CuBr}$ HTL deposited with DMF solvent exhibits best results as compared to the layer deposited from DMSO and $\mathrm{MeCN}$ solvents in both of active-layer combinations. Interestingly, we found that the HTL deposited from three different solvents has significant effects on the FF, whereas it has very little effect on $J_{\mathrm{sc}}$ and $V_{\mathrm{oc}}$. However, the devices that were fabricated using the HTL deposited from DMF and DMSO have slightly higher FF compared to the device using HTL deposited from $\mathrm{MeCN}$ solvent. This may be due to the surface morphology of the HTL films arising during film deposition from different solvents. It may be mentioned here that a small difference of device parameters (PCE, $J_{\text {sc }} \mathrm{FF}$, and $V_{\text {oc }}$ ) has been observed between the devices made from DMF and DMSO solvents, whereas a significant difference of the device parameters has been found when the device was prepared from the $\mathrm{MeCN}$ solvent. This may be due to the lower boiling point of $\mathrm{MeCN}$ as compared to the DMF and DMSO.

2.4. Surface Morphological Result. We have investigated the morphology of the CuBr-deposited HTL from different solvents to understand the slight variation of cell parameters (PCE, $J_{s c}, F F$, and $V_{\text {oc }}$ ) of the devices. AFM images were recorded of the HTLs deposited from different solvents on ITO substrates. The AFM images of ITO/CuBr (DMF), ITO/ $\mathrm{CuBr}(\mathrm{DMSO})$, and $\mathrm{ITO} / \mathrm{CuBr}(\mathrm{MeCN})$ are shown in Figure 7. It may be mentioned here that the FF of the device depends on the morphology of the HTL. From these images, we have clearly seen the changes in film morphology by changing the deposition solvents of the HTL, but the difference is not noticeable. However, the $\mathrm{CuBr}$ film deposited from $\mathrm{DMF}$ solvent has a relatively smoother surface as compared to DMSO and $\mathrm{MeCN}$ solvents because the average roughness values of $\mathrm{CuBr}$ films deposited from DMF, DMSO, and MeCN solvents are 2.71, 5.33, and $8.81 \mathrm{~nm}$, respectively. The smoother interface between $\mathrm{CuBr}$ and active layers may allow for better contact; as a result, it improves the device performance $\left(J_{s c}, \mathrm{FF}\right.$, and $\left.V_{\mathrm{oc}}\right)$ as well as efficiency of the device. Despite the surface morphology, the volume of the thin film is also important for the performance of the OSC because of the thin-film volume corresponding to the size of the layer and domains and thereby of the typically active area of the device and related to exciton generation, diffusion, dissociation, and charge transport. ${ }^{47}$

\section{CONCLUSIONS}

In conclusion, for the first time, we have demonstrated $\mathrm{CuBr}$ as a solution-processable, efficient, and inexpensive inorganic HTL for cost-effective OSC fabrication. The $\mathrm{CuBr}$ thin film deposited from different solvents are highly transparent. The importance of $\mathrm{CuBr}$ as a common hole transport material was examined by device fabrication of OSCs based on two wellreported donor materials PTB7 and PCDTBT. The resulting devices based on $\mathrm{CuBr}$ as a HTL show comparable PCE as previously reported traditional HTLs such as PEDOT/PSS, $\mathrm{CuI}, \mathrm{CuSCN}$, and so forth. To understand the importance of the material in general, three different solvents-DMF, DMSO, and $\mathrm{MeCN}$ - were used for solution-processing thinfilm deposition. We found that the HTL deposited from three
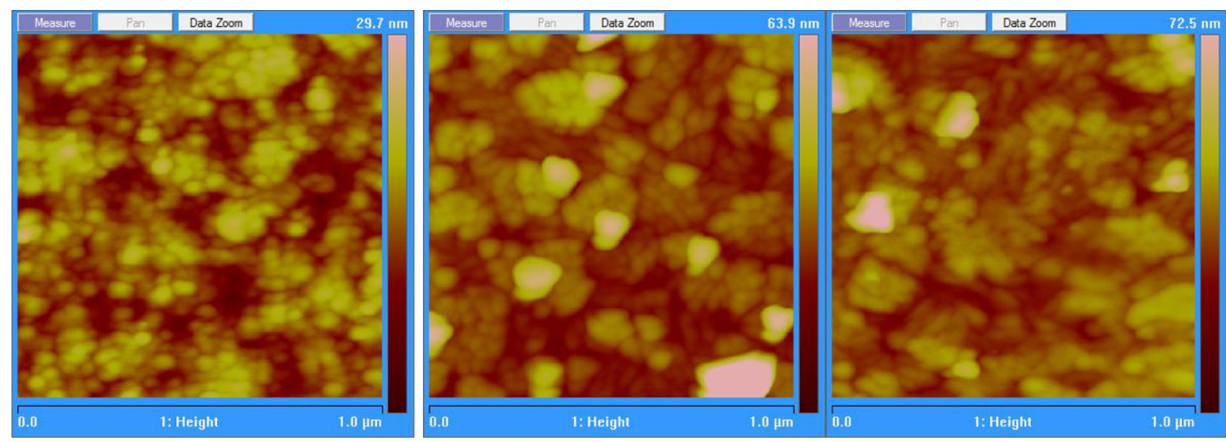

Figure 7. AFM images of (left) ITO/CuBr (DMF), (middle) ITO/CuBr (DMSO), and (right) ITO/CuBr (MeCN). 
different solvents show very good performance. We have shown that the deposition solvents of the HTL in solar cells have a major effect on FF, whereas they have a minor effect on $J_{\text {sc }}$ and $V_{\mathrm{oc}}$ although the difference of the device parameters (PCE, $J_{\text {sc }}, \mathrm{FF}$, and $V_{\mathrm{oc}}$ ) are significant for the device using the HTL deposited from MeCN solvent. The reason behind this observation is the surface morphology of the $\mathrm{CuBr}$ film in different solvents and volatile nature of solvents. The key advantages of solution-processable $\mathrm{CuBr}$ as a HTL are high transparency, easy deposition, nontoxicity, and low cost, which are essential for possible large-area OSCs.

\section{EXPERIMENTAL SECTION}

4.1. Reagents and Materials. The polymers poly $\left[N-9^{\prime \prime}-\right.$ heptadecanyl-2,7-carbazole-alt-5,5-(4',7'-di-2-thienyl-2', $1^{\prime}, 3^{\prime}$ benzothiadiazole) (PCDTBT) and poly[4,8-bis[(2ethylhexyl)oxy] benzo[ $\left.1,2-b: 4,5-b^{\prime}\right]$ dithiaphene-2,6-diyl] [3fluro-2-[(2-ethylhexyl)cabonyl] thieno[3,4-b] thiophenyldiyl]] (PTB7) and acceptor phenyl- $\mathrm{C}_{71}$-butyric acid methyl ester $\left(\mathrm{PC}_{71} \mathrm{BM}\right)$ were purchased from Ossila Limited, United Kingdom. Copper bromide $(\mathrm{CuBr})$ and solvents such as 1,2dichlorobenzene (DCB), chlorobenzene $(\mathrm{CB})$, diiodooctane (DIO), MeCN, DMSO, and DMF were purchased from Sigma Aldrich. All these commercially available chemicals were used without further purification.

4.2. Preparation of the $\mathrm{CuBr}$ Layer as HTLs. $\mathrm{CuBr}$ material $(50 \mathrm{mg})$ was dissolved in $5.0 \mathrm{~mL}$ solvent and the combined mixture was sonicated for $2 \mathrm{~h}$ at room temperature. After sonication, the resulting suspension was capped for 30 min at room temperature. The insoluble portion of the mixture settled down. The clear solution of the upper layer was used for solution-processable HTL deposition in OSCs.

4.3. Preparation of Active-Layer Solution. Here, the devices were fabricated using two most studied active layers of $\mathrm{PCDTBT} / \mathrm{PC}_{71} \mathrm{BM}$ and $\mathrm{PTB} 7 / \mathrm{PC}_{71} \mathrm{BM}$. Donor polymer PCDTBT and acceptor $\mathrm{PC}_{71} \mathrm{BM}$ were used in a 1.0:4.0 w/w ratio and dissolved in mixture solvents of $\mathrm{CB}$ and $\mathrm{DCB}(1.0$ / $3.0 \mathrm{v} / \mathrm{v})$. The concentration of the solution is $35 \mathrm{mg} / \mathrm{mL}$. Another donor-acceptor combination $\mathrm{PTB} 7 / \mathrm{PC}_{71} \mathrm{BM}$ was used (ratio 1.0:1.5 w/w) and dissolved in a solution of DIO in $\mathrm{CB}$ (ratio 3.0:97.0 v/v). The concentration of the solution is $25 \mathrm{mg} / \mathrm{mL}$. Both the active-layer solutions were stirred for $12 \mathrm{~h}$ at room temperature before being used.

4.4. Device Fabrication Process. ITO-coated glass substrates $\left(\sim 12 \Omega / \mathrm{cm}^{2}\right)$ were used as an anode for device fabrication. The laser ablation method was used to pattern the ITO on the glass substrate. The patterned ITO-coated glass substrates were cleaned by soap solution followed by boiling acetone, trichloroethylene, and isopropanol. Finally, the substrates were dried under vacuum for $20 \mathrm{~min}$. Then, the $\mathrm{CuBr}(\sim 35 \mathrm{~nm})$ thin film was deposited on the cleaned substrates by spin-coating at $3000 \mathrm{rpm}$ for $60 \mathrm{~s}$ from the three different solution of $\mathrm{CuBr}$. The resulting HTLs were baked on the hot plate at $100{ }^{\circ} \mathrm{C}$ for $15 \mathrm{~min}$ and then drying for $1 \mathrm{~h}$ at room temperature. The active layer $(\sim 70 \mathrm{~nm})$ was deposited by spin-coating with $1000 \mathrm{rpm}$ for $90 \mathrm{~s}$ onto the HTL and annealed for $10 \mathrm{~min}$ at $70{ }^{\circ} \mathrm{C}$ on a hot plate inside the glovebox (inert condition). The final cathode electrode of $\mathrm{Al}$ $(\sim 110 \mathrm{~nm})$ was thermally deposited on the active layer. The completed devices were then transferred for the characterization.

4.5. Characterization. The absorption and transmission of $\mathrm{CuBr}$ thin films were recorded by a UV-1800 Shimadzu spectrophotometer. The film morphology of $\mathrm{CuBr}$ films deposited from different solvents on ITO-coated glass substrates was measured by atomic force microscopy (AFM) NT-MDT Solver Pro. The $J-V$ measurements of the devices were performed using a Keithley 2400 source meter. A solar simulator (AM $1.5 \mathrm{G}$ ) and incident power $\left(100 \mathrm{~mW} / \mathrm{cm}^{2}\right)$ were used for device characterization.

4.6. Computational Details. Density functional theory with the B3LYP hybrid functional ${ }^{50}$ and the $3-21 \mathrm{G}$ basis set was used for all theoretical calculations. The Gaussian 03 program was used for all computations. The structures of the molecules were fully optimized using a hybrid density theory.

\section{ASSOCIATED CONTENT}

\section{Supporting Information}

The Supporting Information is available free of charge on the ACS Publications website at DOI: 10.1021/acsomega.8b03038.

Absolute energies of the optimized structures; optimized structure of $\mathrm{CuBr}, \mathrm{CuI}$, and $\mathrm{CuSCN}$; represented molecular orbitals $\mathrm{CuBr}, \mathrm{CuI}$, and $\mathrm{CuSCN} ; J-V$ characteristics of $\mathrm{PTB} 7 / \mathrm{PC}_{71} \mathrm{BM}$ and PCDTBT/ $\mathrm{PC}_{71} \mathrm{BM}$ devices under dark; and $J-V$ characteristics of $\mathrm{PTB} 7 / \mathrm{PC}_{71} \mathrm{BM}$ and $\mathrm{PCDTBT} / \mathrm{PC}_{71} \mathrm{BN}$ devices without $\operatorname{HTL}(\mathrm{PDF})$

\section{AUTHOR INFORMATION}

\section{Corresponding Author}

*E-mail: apatra@nplindia.org (A.P.).

ORCID $\odot$

Asit Patra: 0000-0002-3492-9147

Notes

The authors declare no competing financial interest.

\section{ACKNOWLEDGMENTS}

This work is financial supported by SERI-DST, New Delhi, an energy initiative project entitled "Development of New Interfacial layer for efficient and stable Excitonic solar cells”.

\section{REFERENCES}

(1) (a) Krebs, F. C.; Espinosa, N.; Hösel, M.; Søndergaard, R. R.; Jørgensen, M. 25th Anniversary article: rise to power-OPV-based solar parks. Adv. Mater. 2014, 26, 29-39. (b) Li, N.; Baran, D.; Spyropoulos, G. D.; Zhang, H.; Berny, S.; Turbiez, M.; Ameri, T.; Krebs, F. C.; Brabec, C. J. Environmentally printing efficient organic tandem solar cells with high fill factors: a guideline towards $20 \%$ power conversion efficiency. Adv. Energy Mater. 2014, 4, 1400084.

(2) (a) Patra, A.; Bendikov, M.; Chand, S. Poly (3,4-ethylenedioxyselenophene) and its derivatives: novel organic electronic materials. Acc. Chem. Res. 2014, 47, 1465-1474. (b) Patra, A.; Kumar, $\mathrm{R}$; Chand, S. Selenium-Containing $\pi$-Conjugated Polymers for Organic Solar Cells. Isr. J. Chem. 2014, 54, 621-641.

(3) Khodabakhsh, S.; Poplavskyy, D.; Heutz, S.; Nelson, J.; Bradley, D. D. C.; Murata, H.; Jones, T. S. Using Self-Assembling Dipole Molecules to Improve Hole Injection in Conjugated Polymers. Adv. Funct. Mater. 2004, 14, 1205-1210.

(4) Tokmoldin, N.; Griffiths, N.; Bradley, D. D. C.; Haque, S. A. A Hybrid Inorganic-Organic Semiconductor Light-Emitting Diode Using $\mathrm{ZrO}_{2}$ as an Electron-Injection Layer. Adv. Mater. 2009, 21, $3475-3478$

(5) (a) Zhang, F.; Johansson, M.; Andersson, M. R.; Hummelen, J. C.; Inganäs, $\mathrm{O}$. Polymer photovoltaic cells with conducting polymer anodes. Adv. Mater. 2002, 14, 662-665. (b) Namkoong, G.; Younes, E. M.; Abdel-Fattah, T. M.; El-Maghraby, E. M.; Elsayed, A. H.; Abo 
Elazm, A. H. Aging process of PEDOT: PSS dispersion and robust recovery of aged PEDOT: PSS as a hole transport layer for organic solar cells. Org. Electron. 2015, 25, 237-244. (c) Chaudhary, N.; Chaudhary, R.; Kesari, J. P.; Patra, A. Effect of composition ratio of P3HT: PC61BM in organic solar cells: optical and morphological properties. Mater. Res. Innovations 2018, 22, 282-286.

(6) (a) Gupta, D.; Wienk, M. M.; Janssen, R. A. J. Efficient Polymer Solar Cells on Opaque Substrates with a Laminated PEDOT:PSS Top Electrode. Adv. Energy Mater. 2103, 3, 782-787. (b) Li, G.; Shrotriya, V.; Huang, J.; Yao, Y.; Moriarty, T.; Emery, K.; Yang, Y. Highefficiency solution processable polymer photovoltaic cells by selforganization of polymer blends. Nat. Mater. 2011, 80-84. (c) Xia, Y.; Zhang, H.; Ouyang, J. Highly conductive PEDOT: PSS films prepared through a treatment with zwitterions and their application in polymer photovoltaic cells. J. Mater. Chem. 2010, 20, 9740-9747.

(7) (a) Meskers, S. C. J.; Van Duren, J. K. J.; Janssen, R. A. J. Nonlinearity in the I-V characteristic of poly (3,4-ethylenedioxythiophene): poly (styrenesulfonic acid)(PEDOT: PSS) due to Joule heating. Org. Electron. 2004, 5, 207-211. (b) Wong, K. W.; Yip, H. L.; Luo, Y.; Wong, K. Y.; Lau, W. M.; Low, K. H.; Chow, H. F.; Gao, Z. Q.; Yeung, W. L.; Chang, C. C. Blocking reactions between indiumtin oxide and poly (3,4-ethylene dioxythiophene): poly (styrene sulphonate) with a self-assembly monolayer. Appl. Phys. Lett. 2002, $80,2788-2790$

(8) Kemerink, M.; Timpanaro, S.; De Kok, M. M.; Meulenkamp, E. A.; Touwslager, F. J. Three-dimensional inhomogeneities in PEDOT: PSS films. J. Phys. Chem. B 2004, 108, 18820-18825.

(9) Bhargav, R.; Bhardwaj, D.; Shahjad, P. A.; Patra, A.; Chand, S. Poly (Styrene Sulfonate) Free Poly (3,4-Ethylenedioxythiophene) as a Robust and Solution-Processable Hole Transport Layer for Organic Solar Cells. ChemistrySelect 2016, 1, 1347-1352.

(10) (a) Triantou, D.; Soulis, S.; Koureli, S.; De Sio, A.; Von Hauff, E. Thiophene-based copolymers synthesized by electropolymerization for application as hole transport layer in organic solar cells. J. Appl. Polym. Sci. 2013, 127, 585-592. (b) Lacher, S.; Obata, N.; Luo, S.-C.; Matsuo, Y.; Zhu, B.; Yu, H.-h.; Nakamura, E.; Lacher, S.; Obata, N.; Luo, S. C.; Matsuo, Y.; Zhu, B.; Yu, H. H.; Nakamura, E. Electropolymerized conjugated polyelectrolytes with tunable work function and hydrophobicity as an anode buffer in organic optoelectronics. ACS Appl. Mater. Interfaces 2012, 4, 3396-3404.

(11) Levermore, P. A.; Chen, L.; Wang, X.; Das, R.; Bradley, D. D. C. Fabrication of highly conductive poly (3,4-ethylenedioxythiophene) films by vapor phase polymerization and their application in efficient organic light-emitting diodes. Adv. Mater. 2007, 19, 23792385 .

(12) Wang, X.; Ishwara, T.; Gong, W.; Campoy-Quiles, M.; Nelson, J.; Bradley, D. D. C. High-Performance Metal-Free Solar Cells Using Stamp Transfer Printed Vapor Phase Polymerized Poly (3,4Ethylenedioxythiophene) Top Anodes. Adv. Funct. Mater. 2012, 22, 1454-1460.

(13) (a) Li, S.-S.; Tu, K.-H.; Lin, C.-C.; Chen, C.-W.; Chhowalla, M. Solution-processable graphene oxide as an efficient hole transport layer in polymer solar cells. ACS Nano 2010, 4, 3169-3174. (b) Sun, B.; Zhou, D.; Wang, C.; Liu, P.; Hao, Y.; Han, D.; Feng, L.; Zhou, Y. Copper (II) chloride doped graphene oxides as efficient hole transport layer for high-performance polymer solar cells. Org. Electron. 2017, 44, 176-182.

(14) Wei, J.; Jia, Y.; Shu, Q.; Gu, Z.; Wang, K.; Zhuang, D.; Zhang, G.; Wang, Z.; Luo, J.; Cao, A.; Wu, D. Double- walled carbon nanotube solar cells. Nano Lett. 2007, 7, 2317-2321.

(15) Han, Y.-K.; Chang, M.-Y.; Ho, K.-S.; Hsieh, T.-H.; Tsai, J.-L.; Huang, P.-C. Electrochemically deposited nano polyaniline films as hole transporting layers in organic solar cells. Sol. Energy Mater. Sol. Cells 2014, 128, 198-203.

(16) Shrotriya, V.; Li, G.; Yao, Y.; Chu, C. W.; Yang, Y. Transition metal oxides as the buffer layer for polymer photovoltaic cells. Appl. Phys. Lett. 2006, 88, 073508.

(17) (a) Irwin, M. D.; Buchholz, D. B.; Hains, A. W.; Chang, R. P. H.; Marks, T. J. p-Type semiconducting nickel oxide as an efficiency- enhancing anode interfacial layer in polymer bulk-heterojunction solar cells. Proc. Natl. Acad. Sci. U.S.A. 2008, 105, 2783-2787. (b) Chavhan, S. D.; Hansson, R.; Ericsson, L. K. E.; Beyer, P.; Hofmann, A.; Brütting, W.; Opitz, A.; Moons, E. Low temperature processed NiOx hole transport layers for efficient polymer solar cells. Org. Electron. 2017, 44, 59-66.

(18) Irwin, M. D.; Servaites, J. D.; Buchholz, D. B.; Leever, B. J.; Liu, J.; Emery, J. D.; Zhang, M.; Song, J.-H.; Durstock, M. F.; Freeman, A. J.; Bedzyk, M. J.; Bedzyk, M. J.; Hersam, M. C.; Chang, R. P. H.; Ratner, M. A.; Marks, T. J. Structural and electrical functionality of $\mathrm{NiO}$ interfacial films in bulk heterojunction organic solar cells. Chem. Mater. 2011, 23, 2218-2226.

(19) Girotto, C.; Voroshazi, E.; Cheyns, D.; Heremans, P.; Rand, B. P. Solution-processed $\mathrm{MoO}_{3}$ thin films as a hole-injection layer for organic solar cells. ACS Appl. Mater. Interfaces 2011, 3, 3244-3247.

(20) Stubhan, T.; Ameri, T.; Salinas, M.; Krantz, J.; Machui, F.; Halik, M.; Brabec, C. J. High shunt resistance in polymer solar cells comprising a $\mathrm{MoO}_{3}$ hole extraction layer processed from nanoparticle suspension. Appl. Phys. Lett. 2011, 98, 253308.

(21) Steirer, K. X.; Chesin, J. P.; Widjonarko, N. E.; Berry, J. J.; Miedaner, A.; Ginley, D. S.; Olson, D. C. Solution deposited NiO thin-films as hole transport layers in organic photovoltaics. Org. Electron. 2010, 11, 1414-1418.

(22) Xu, Q.; Wang, F.; Tan, Z. A.; Li, L.; Li, S.; Hou, X.; Sun, G.; Tu, X.; Hou, J.; Li, Y. High-Performance Polymer Solar Cells with Solution-Processed and Environmentally Friendly $\mathrm{CuO}$ x Anode Buffer Layer. ACS Appl. Mater. Interfaces 2013, 5, 10658-10664.

(23) Tan, Z. A.; Qian, D.; Zhang, W.; Li, L.; Ding, Y.; Xu, Q.; Wang, F.; Li, Y. Efficient and stable polymer solar cells with solutionprocessed molybdenum oxide interfacial layer. J. Mater. Chem. A 2013, 1, 657-664.

(24) Yang, T.; Wang, M.; Cao, Y.; Huang, F.; Huang, L.; Peng, J.; Gong, X.; Cheng, S. Z. D.; Cao, Y. Polymer Solar Cells with a LowTemperature-Annealed Sol-Gel-Derived $\mathrm{MoOx}$ Film as a Hole Extraction Layer. Adv. Energy Mater. 2012, 2, 523-527.

(25) Hammond, S. R.; Meyer, J.; Widjonarko, N. E.; Ndione, P. F.; Sigdel, A. K.; Garcia, A.; Miedaner, A.; Lloyd, M. T.; Kahn, A.; Ginley, D. S.; Berry, J. J.; Olson, D. C. Low-temperature, solution-processed molybdenum oxide hole-collection layer for organic photovoltaics. $J$. Mater. Chem. 2012, 22, 3249-3254.

(26) Tan, Z. A.; Li, L.; Wang, F.; Xu, Q.; Li, S.; Sun, G.; Tu, X.; Hou, X.; Hou, J.; Li, Y. Solution-Processed Rhenium Oxide: A Versatile Anode Buffer Layer for High Performance Polymer Solar Cells with Enhanced Light Harvest. Adv. Energy Mater. 2014, 4, 1300884.

(27) Tan, Z. A.; Zhang, W.; Cui, C.; Ding, Y.; Qian, D.; Xu, Q.; Li, L.; Li, S.; Li, Y. Solution-Processed Vanadium Oxide as a Hole Collection Layer on an ITO Electrode for High-Performance Polymer Solar Cells. Phys. Chem. Chem. Phys. 2012, 14, 14589-14595.

(28) Zilberberg, K.; Trost, S.; Schmidt, H.; Riedl, T. Solution Processed Vanadium Pentoxide as Charge Extraction Layer for Organic Solar Cells. Adv. Energy Mater. 2011, 1, 377-381.

(29) Wong, K. H.; Ananthanarayanan, K.; Heinemann, M. D.; Luther, J.; Balaya, P. Enhanced photocurrent and stability of organic solar cells using solution-based $\mathrm{NiO}$ interfacial layer. Sol. Energy 2012, 86, 3190-3195.

(30) Steirer, K. X.; Ndione, P. F.; Widjonarko, N. E.; Lloyd, M. T.; Meyer, J.; Ratcliff, E. L.; Kahn, A.; Armstrong, N. R.; Curtis, C. J.; Ginley, D. S.; Berry, J. J.; Olson, D. C. Enhanced efficiency in plastic solar cells via energy matched solution processed $\mathrm{NiOx}$ interlayers. Adv. Energy Mater. 2011, 1, 813-820.

(31) Trost, S.; Zilberberg, K.; Behrendt, A.; Riedl, T. Roomtemperature solution processed $\mathrm{SnO} \mathrm{x}$ as an electron extraction layer for inverted organic solar cells with superior thermal stability. J. Mater. Chem. A 2012, 22, 16224-16229.

(32) Tan, Z. A.; Li, L.; Cui, C.; Ding, Y.; Xu, Q.; Li, S.; Qian, D.; Li, Y. Solution-processed tungsten oxide as an effective anode buffer layer for high-performance polymer solar cells. J. Phys. Chem. C 2012, 116, 18626-18632. 
(33) Wang, F.; Xu, Q.; Tan, Z. A.; Li, L.; Li, S.; Hou, X.; Sun, G.; $\mathrm{Tu}, \mathrm{X}$.; Hou, J.; Li, Y. Efficient polymer solar cells with a solutionprocessed and thermal annealing-free $\mathrm{RuO}_{2}$ anode buffer layer. $J$. Mater. Chem. A 2014, 2, 1318-1324.

(34) Bhargav, R.; Patra, A.; Dhawan, S. K.; Gairola, S. P. Solution processed hole transport layer towards efficient and cost effective organic solar cells. Sol. Energy 2018, 165, 131-135.

(35) Gross, N. Y.; Treat, N. D.; Pattanasattayavong, P.; Faber, H.; Perumal, A. K.; Stingelin, N.; Bradley, D. D. C.; Stavrinou, P. N.; Heeney, M.; Anthopoulos, T. D. High-Efficiency Organic Photovoltaic Cells Based on the Solution-Processable Hole Transporting Interlayer Copper Thiocyanate (CuSCN) as a Replacement for PEDOT: PSS. Adv. Energy Mater. 2015, 5, 1401529.

(36) Treat, N. D.; Gross, N. Y.; Faber, H.; Perumal, A. K.; Bradley, D. D. C.; Stingelin, N.; Anthopoulos, T. D. Copper thiocyanate: An attractive hole transport/extraction layer for use in organic photovoltaic cells. Appl. Phys. Lett. 2015, 107, 013301.

(37) (a) Chaudhary, N.; Chaudhary, R.; Kesari, J. P.; Patra, A.; Chand, S. Copper thiocyanate (CuSCN): an efficient solutionprocessable hole transporting layer in organic solar cells. J. Mater. Chem. C 2015, 3, 11886-11892. (b) Chaudhary, N.; Chaudhary, R.; Kesari, J. P.; Patra, A. An eco-friendly and inexpensive solvent for solution processable $\mathrm{CuSCN}$ as a hole transporting layer in organic solar cells. Opt. Mater. 2017, 69, 367-371.

(38) Sun, W.; Peng, H.; Li, Y.; Yan, W.; Liu, Z.; Bian, Z.; Huang, C. Solution-processed copper iodide as an inexpensive and effective anode buffer layer for polymer solar cells. J. Phys. Chem. C 2014, 118, 16806.

(39) Das, S.; Choi, J.-Y.; Alford, T. L. PC ${ }_{61} \mathrm{BM}$ based solar cells employing solution processed copper iodide as the hole transport layer. Sol. Energy Mater. Sol. Cells 2015, 133, 255-259.

(40) Peng, Y.; Yaacobi-Gross, N.; Perumal, A. K.; Faber, H. A.; Vourlias, G.; Patsalas, P. A.; Bradley, D. D. C.; He, Z.; Anthopoulos, T. D. Efficient organic solar cells using copper (I) iodide (CuI) hole transport layers. Appl. Phys. Lett. 2015, 106, 243302.

(41) Taima, T.; Shahiduzzaman, M.; Ishizeki, T.; Yamamoto, K.; Karakawa, M.; Kuwabara, T.; Takahashi, K. Sexithiophene-Based Photovoltaic Cells with High Light Absorption Coefficient via Crystalline Polymorph Control. J. Phys. Chem. C 2017, 121, 19699-19704.

(42) Zhao, K.; Ngongang Ndjawa, G. O.; Jagadamma, L. K.; Labban, A. E.; Hu, H.; Wang, Q.; Li, R.; Abdelsamie, M.; Beaujuge, P. M.; Amassia, A.; Amassian, A. Highly efficient organic solar cells based on a robust room-temperature solution-processed copper iodide hole transporter. Nano Energy 2015, 16, 458-469.

(43) Dang, M. T.; Hirsch, L.; Wantz, G. P ${ }_{3}$ HT:PCBM, best seller in polymer photovoltaic research. Adv. Mater. 2011, 23, 3597-3602.

(44) Li, Z.; Guo, W.; Liu, C.; Zhang, X.; Li, S.; Guo, J.; Zhang, L. Impedance investigation of the highly efficient polymer solar cells with composite $\mathrm{CuBr}{ }_{2} / \mathrm{MoO}_{3}$ hole transport layer. Phys. Chem. Chem. Phys. 2017, 19, 20839-20846.

(45) Kim, T.-M.; Kim, H. J.; Shim, H.-S.; Choi, M.-S.; Kim, J. W.; Kim, J.-J. The epitaxial growth of lead phthalocyanine on copper halogen compounds as the origin of templating effects. J. Mater. Chem. A 2014, 2, 8730-8735.

(46) Zhao, Z.; Wu, Q.; Xia, F.; Chen, X.; Liu, Y.; Zhang, W.; Zhu, J.; Dai, S.; Yang, S. Improving the conductivity of PEDOT:PSS hole transport layer in polymer solar cells via copper (II) bromide salt doping. ACS Appl. Mater. Interfaces 2015, 7, 1439-1448.

(47) (a) Ruderer, M. A.; Guo, S.; Meier, R.; Chiang, H.-Y.; Körstgens, V.; Wiedersich, J.; Perlich, J.; Roth, S. V.; MüllerBuschbaum, P. Solvent-induced morphology in polymer-based systems for organic photovoltaics. Adv. Funct. Mater. 2011, 21, 3382-3391. (b) Schaffer, C. J.; Palumbiny, C. M.; Niedermeier, M. A.; Burger, C.; Santoro, G.; Roth, S. V.; Müller-Buschbaum, P. Morphological Degradation in Low Bandgap Polymer Solar Cells-An In Operando Study. Adv. Energy Mater. 2016, 6, 1600712.

(48) (a) Palumbiny, C. M.; Heller, C.; Schaffer, C. J.; Körstgens, V.; Santoro, G.; Roth, S. V.; Müller-Buschbaum, P. Molecular reorientation and structural changes in cosolvent-treated highly conductive PEDOT: PSS electrodes for flexible indium tin oxidefree organic electronics. J. Phys. Chem. C 2014, 118, 13598-13606. (b) Abdel-Fattah, T. M.; Younes, E. M.; Namkoong, G.; El-Maghraby, E. M.; Elsayed, A. H.; Abo Elazm, A. H. Solvents effects on the hole transport layer in organic solar cells performance. Sol. Energy 2016, 137, 337-343. (c) McDowell, C.; Bazan, G. C. Organic solar cells processed from green solvents. Curr. Opin. Green Sustain. Chem. 2017, $5,49-54$.

(49) Chaudhary, N.; Kesari, J. P.; Chaudhary, R.; Patra, A. Low band gap polymeric solar cells using solution-processable copper iodide as hole transporting layer. Opt. Mater. 2016, 58, 116-120.

(50) (a) Parr, R. G.; Yang, W. Density-functional theory of atoms and molecules; Oxford University Press: New York, 1989. (b) Koch, W.; Holthausen, M. C. A chemist's guide to density functional theory; WileyVCH: New York, 2000. (c) Lee, C.; Yang, W.; Parr, R. G. Development of the Colle-Salvetti correlation-energy formula into a functional of the electron density. Phys. Rev. B: Condens. Matter Mater. Phys. 1988, 37, 785. (d) Becke, A. D. Density-functional thermochemistry. III. The role of exact exchange. J. Chem. Phys. 1993, 98, 5648-5652. 